\title{
Facile preparation of copper impregnated aluminum pillared montmorillonite: nanoclays for wastewater treatment
}

\author{
P. TEPMATEE ${ }^{1}$ and P. SIRIPHANNON ${ }^{1,2 *}$ \\ ${ }^{1}$ Functional Nanostructured Materials Laboratory, College of Nanotechnology, King Mongkut's Institute of Technology Ladkrabang, \\ Chalongkrung Road, Ladkrabang, Bangkok 10520, Thailand \\ ${ }^{2}$ Department of Chemistry, Faculty of Science, King Mongkut's Institute of Technology Ladkrabang, Chalongkrung Road, Ladkrabang, \\ Bangkok 10520, Thailand
}

\begin{abstract}
Copper impregnated aluminum pillared montmorillonites ( $\mathrm{Cu}$-iAlpill-MMTs) were prepared by adding $\mathrm{Cu}^{2+}$ solution into dried aluminum polyohydroxy cation intercalated montmorillonite using various $\mathrm{Cu}^{2+}$ concentrations, i.e. 4, 7, 10 and $13 \mathrm{wt} \%$ and then calcining at $500^{\circ} \mathrm{C}$. The $\mathrm{Cu}$-iAlpill-MMTs possessed slit-liked mesopores with pore diameters of 3.3-3.8 $\mathrm{nm}$ and $\sim 6-35 \mathrm{~nm}$ as observed from the nitrogen adsorption isotherms. The mesopore quantities of $\mathrm{Cu}$-iAlpill-MMTs gradually decreased with the increase of impregnated $\mathrm{Cu}^{2+}$ concentrations. The impregnated $\mathrm{CuO}$ occupied not only the interior interlayers, but also the exterior surfaces of Cu-iAlpill-MMTs. The Cu-iAlpill-MMTs with 10 and $13 \mathrm{wt} \%$ of impregnated $\mathrm{Cu}^{2+}$ could inhibit the growth of Escherichia coli. The Cu-iAlpill-MMTs effectively acted as the heterogeneous catalyst for removal reactive orange 16 (RO16) in Fenton or photo-Fenton oxidation treatments. The higher impregnated $\mathrm{Cu}^{2+}$ and/or the longer treatment time brought about the higher percentage of RO16 removal.
\end{abstract}

Key words: pillared montmorillonite, mesoporous materials, impregnation, advanced oxidation processes, adsorption.

\section{Introduction}

Aluminum pillared clays have been considered as adsorbents and catalysts, especially in environmental applications due to their high acidic property, high surface area and porosity, thermal stability, reusability and low cost [1-3]. They are commonly obtained by intercalation of aluminum polyhydroxy cation in the interlayer of clays and followed by calcinations [4-5]. In addition, some research works have modified the aluminum pillared clays by doping the transition metals, such as $\mathrm{Cr}, \mathrm{Ag}$, $\mathrm{V}, \mathrm{Fe}, \mathrm{Mn}, \mathrm{Ti}, \mathrm{Ce}, \mathrm{Pd}, \mathrm{Cu}$, etc., in order to create the active sites for the catalysis reactions [6-7]. Among various transition metals, the copper $(\mathrm{Cu})$ have attracted considerable attention as the dopant because it could induce the catalytic oxidation via Fenton and photo-Fenton reactions [8], resulting in the degradation of various organic pollutants, such as synthetic dyes [9-11], phenol [12], olive oil mill [13], agro food [14], etc. Besides, the $\mathrm{Cu}$ dopant could also inhibit bacterial growth, indicating its antibacterial property [15-16].

From the attractive properties of $\mathrm{Cu}$ dopant, our previous work prepared the $\mathrm{Cu}$ doped aluminum pillared montmorillonite by sonication process [17]. The $\mathrm{Cu}$ doped aluminum pillared montmorillonite acted as the heterogeneous catalyst for effective removal the reactive dye, however, the quantity amount of doped $\mathrm{Cu}$ in the pillared structure could not be exactly controlled in the sonication process. Therefore, the present work aimed to prepare the $\mathrm{Cu}$ doped aluminum pillared montmoril-

*e-mail: punnama.si@kmitl.ac.th lonite using facile impregnation method, in which the $\mathrm{Cu}$ doped amount was controllable. The $\mathrm{Cu}$ impregnation was performed using the aluminum polyhydroxy cation intercalated montmorillonite as the host substrate since the intercalated aluminum polyhydroxy cation could enlarge the interlayer space of montmorillonite, resulting in the increase of impregnated $\mathrm{Cu}$ uptake. In addition, the concentration of impregnated $\mathrm{Cu}$ was varied in order to investigate its effect on the structure and properties of the resultant products since the $\mathrm{Cu}$ quantity was considered to play an important role in the catalytic activity and antibacterial property.

The catalytic oxidation activities of the as-prepared $\mathrm{Cu}$ impregnated aluminum pillared montmorillonites were investigated for removal reactive orange 16 (RO16). This reactive dye was used as a model dye containing wastewater because it was commonly used in textile industries due to its easy application in dyeing process and stability during usage [18]. However, the stability of reactive dyes resulted in the difficulty in elimination by biological and conventional wastewater treatments, therefore; the reactive dyes were important pollutants from the textile effluents. The as-prepared $\mathrm{Cu}$ impregnated aluminum pillared montmorillonites were considered to promote the decolourisation, degradation and mineralisation of reactive dye from the model wastewater.

\section{Experiment}

2.1. Materials. Sodium montmorillonite $\left(\mathrm{Na}^{+}-\mathrm{MMT}\right)$ with the cation exchange capacity of about $1.0 \mathrm{meq} / \mathrm{g}$ was supported 


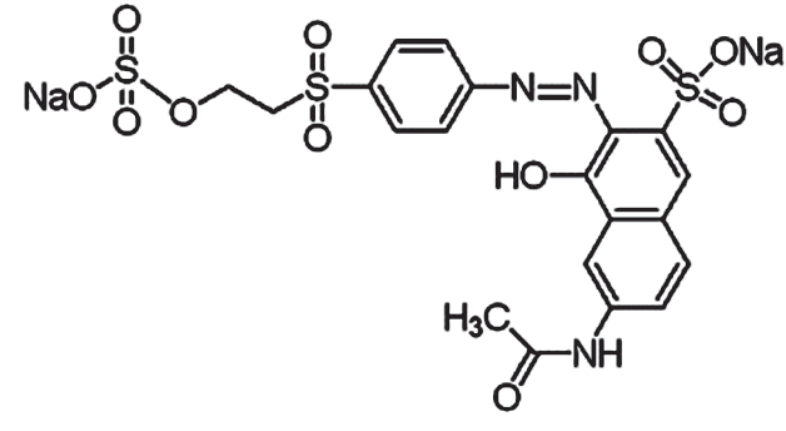

Fig. 1. Chemical structure of reactive orange 16

from Thai Nippon Chemical Industry Co., Ltd. (Thailand). The $\mathrm{Na}^{+}-\mathrm{MMT}$ was purified to remove some contaminants by dispersion and sonication in distilled water for $10 \mathrm{~min}$. The upper layer of swollen $\mathrm{Na}^{+}$-MMT suspension was decanted and dried at $100^{\circ} \mathrm{C}$ for 24 hours. Aluminum nitrate nonahydrate $\left(\mathrm{Al}\left(\mathrm{NO}_{3}\right)_{3} \cdot 9 \mathrm{H}_{2} \mathrm{O}, 98 \%\right)$ was purchased from Rankem. Copper (II) sulfate pentahydrate $\left(\mathrm{CuSO}_{4} \cdot 5 \mathrm{H}_{2} \mathrm{O}, 98 \%\right)$ and sodium hydroxide $(\mathrm{NaOH}, 97 \%)$ were purchased from Carlo Erba.

Reactive Orange 16 (RO16, dye content 70\%) was purchased from Sigma Aldrich, whose structure was shown in Fig. 1. Hydrogen peroxide $\left(\mathrm{H}_{2} \mathrm{O}_{2}, 35 \% \mathrm{v} / \mathrm{v}\right)$ was purchased from QRëC chemical.

2.2. Preparation of copper impregnated aluminum pillared montmorillonites. An aluminum polyhydroxy cation solution $(\mathrm{AlOH})$ with $\mathrm{OH} / \mathrm{Al}$ molar ratio of 2.4 was obtained by mixing $0.4 \mathrm{M} \mathrm{NaOH}$ and $0.4 \mathrm{M} \mathrm{Al}\left(\mathrm{NO}_{3}\right)_{3} \cdot 9 \mathrm{H}_{2} \mathrm{O}$ with continuous stirring for 3 hours at $60^{\circ} \mathrm{C}$ and then aged overnight at room temperature. The prepared $\mathrm{AlOH}$ solution was slowly added into an aqueous $\mathrm{Na}^{+}-\mathrm{MMT}$ suspension with vigorous stirring. The ratio of $\mathrm{mmol}-\mathrm{Al}^{3+} / \mathrm{g}-\mathrm{Na}^{+}-\mathrm{MMT}$ used in the intercalation process was fixed at 2.5. After 24-hour mixing, the mixture suspension was filtered, washed several times with distilled water and dried overnight at $100^{\circ} \mathrm{C}$ in order to obtain the $\mathrm{AlOH}$ intercalated $\mathrm{Na}^{+}-\mathrm{MMT}$ (AlOH-MMT). The $\mathrm{AlOH}-\mathrm{MMT}$ was impregnated with the $\mathrm{CuSO}_{4} \cdot 5 \mathrm{H}_{2} \mathrm{O}$ aqueous solution having various concentration of $\mathrm{Cu}^{2+}$, i.e. $4,7,11$ and $13 \mathrm{wt} \%$ of $\mathrm{AlOH}-\mathrm{MMT}$. The impregnated products were dried overnight at $100^{\circ} \mathrm{C}$ and calcined at $500^{\circ} \mathrm{C}$ for 2 hours in order to obtain the copper impregnated aluminum pillared MMTs (Cu-iAlpill-MMTs).

The starting $\mathrm{Na}^{+}-\mathrm{MMT}$, AlOH-MMT and $\mathrm{Cu}$-iAlpill-MMTs samples were characterized by X-ray fluorescence spectrometer (XRF; Bruker AG, SRS3400) and X-ray diffractometer (XRD; Bruker AG, D8 ADVANCE) in order to determine their chemical compositions and crystalline structure, respectively. Nitrogen adsorption isotherms of starting $\mathrm{Na}^{+}$-MMT and the $\mathrm{Cu}$-iAlpill-MMTs were performed at $-196^{\circ} \mathrm{C}$ using Quantachrome Autosorb 1 for determination of their specific surface areas (SSA), pore volumes and pore size distributions. Prior to evaluating the nitrogen adsorption, all samples were outgassed at $300^{\circ} \mathrm{C}$ for 3 hours. Surface morphologies of the $\mathrm{Cu}-\mathrm{iAl}-$ pill-MMTs were investigated by scanning electron microscope
(SEM; JEOL, JSM-5410) and the elemental distribution of copper $(\mathrm{Cu})$ on the $\mathrm{Cu}$-iAlpill-MMTs surfaces was determined by energy dispersive X-ray microanalysis (EDX) incorporated with the SEM.

2.3. Antibacterial activity test. The antibacterial activities of Cu-iAlpill-MMTs were performed according to the JIS L 1902: 1998 (Qualitative) technique using Escherichia coli (E.coli) ATCC®25922. One gram of Cu-iAlpill-MMTs was shaped by uniaxial pressing into cylindrical pellet with $1.3 \pm 0.1 \mathrm{~cm}$ in diameter. The pellet of $\mathrm{Cu}$-iAlpill-MMTs was placed on the surface of agar plate inoculated with a cell suspension of E.coli and then incubated at $37^{\circ} \mathrm{C}$ for 24 hours. All tests were performed in triplicate according to the standard test method. The size of inhibition zone around the samples was evaluated.

2.4. Determination of dye removal. The $\mathrm{Cu}$-iAlpill-MMTs prepared were used as catalysts for dye removal in Fenton and photo-Fenton systems. An aqueous solution of $300 \mathrm{mg} / \mathrm{L} \mathrm{RO} 16$ was used as a dye-containing wastewater model.

A. Fenton system. The Fenton treatment was performed by mixing $0.2 \mathrm{~g}$ of $\mathrm{Cu}$-iAlpill-MMTs in $20 \mathrm{ml}$ of RO16 solution and $5 \mathrm{ml}$ of $0.1 \mathrm{M}$ hydrogen peroxide $\left(\mathrm{H}_{2} \mathrm{O}_{2}\right)$ with continuous stirring. The treatment times was varied, i.e. 60,120 , 240 and $360 \mathrm{~min}$. After predetermined treatment time, the $\mathrm{Cu}$-iAlpill-MMTs were separated from the mixture solution by centrifugation.

B. Photo-Fenton system. In photo-Fenton treatment, the similar mixture of $\mathrm{Cu}$-iAlpill-MMT, $\mathrm{RO} 16$ and $\mathrm{H}_{2} \mathrm{O}_{2}$ as described above was irradiated with 6W UVC-radiation $(1=254 \mathrm{~nm}$; TUV TL Mini, Philips). The mixture was continuously stirred for various reaction times, i.e. 30, 60, 90, 120, 240 and $360 \mathrm{~min}$. After predetermined treatment time, the $\mathrm{Cu}-$ iAlpill-MMTs were separated from the mixture solution by centrifugation.

The RO16 solutions before and after Fenton and photo-Fenton treatments were analyzed by UV-visible spectrophotometry (UV-Vis; Thermo scientific, Helios omega) at $1_{\max }$ of $388 \mathrm{~nm}$ for RO16. The RO16 concentrations in the dye solutions were evaluated by linear regression equation from the standard calibration curve $\left(\mathrm{Y}=0.0064 \mathrm{X}, \mathrm{R}^{2}=0.9999 ; \mathrm{Y}\right.$ is UV-Vis absorbance and $\mathrm{X}$ is final concentration of RO16 in $\mathrm{mg} / \mathrm{L})$. Percentage of dye removal was calculated from equation (1):

$$
\% \text { dye removal }=\frac{\left(C_{0}-C_{f}\right)}{C_{0}} \times 100,
$$

where $C_{0}$ and $C_{f}$ are initial and final concentrations of dye solutions $(\mathrm{mg} / \mathrm{L})$, respectively.

Total organic carbon (TOC) values in the RO16 solutions before and after Fenton and photo-Fento treatments were analyzed by TOC analyzer (Shimadzu, TOC-VCPH). Percentage of TOC removal was calculated from equation (2):

$$
\% \text { TOC removal }=\frac{\left(\text { TOC }_{0}-\text { TOC }_{f}\right)}{\text { TOC }_{0}} \times 100,
$$

where $T O C_{0}$ and $T O C_{f}$ are initial and final TOC of dye solutions $(\mathrm{mg} / \mathrm{L})$, respectively. 


\section{Results and discussion}

3.1. Characterization of Cu-iAlpill-MMT. Figure 2 shows the XRD patterns of $\mathrm{Cu}$-iAlpill-MMTs are shown in comparison with the starting $\mathrm{Na}^{+}$-MMT and the AlOH-MMT precursor. It was found that the interlayer space of starting $\mathrm{Na}^{+}$-MMT tactoids in Fig. 2a was observed at $2 \approx 7.12^{\circ}$, corresponding to a 001 -plane basal spacing $\left(d_{001}\right)$ of $1.24 \mathrm{~nm}$ as reported in Table 1 . After intercalation with $\mathrm{AlOH}$ solution, the cation exchange between aluminum polyhydroxy cation $\left(\left[\mathrm{AlO}_{4} \mathrm{Al}_{12}(\mathrm{OH})_{24}\left(\mathrm{OH}_{2}\right)_{12}\right]^{7+}\right.$, $\mathrm{Al}_{13}{ }^{7+}$ ) obtained from base hydrolyzation of $\mathrm{Al}\left(\mathrm{NO}_{3}\right)_{3} \cdot 9 \mathrm{H}_{2} \mathrm{O}$ and $\mathrm{Na}^{+}$interlayer counter ions brought about the expansion of MMT tactoids' interlayer space with disorder structure as previously discussed elsewhere [5]. It was therefore the $d_{001}$ peak in Fig. $2 \mathrm{~b}$ was broadened and shifted to $2 \approx 5.1^{\circ}$, corresponding to $d_{001}$ of $1.74 \mathrm{~nm}$. From the XRF analysis, the increases of $\mathrm{Al}_{2} \mathrm{O}_{3}$ quantity and $\mathrm{Al} / \mathrm{Si}$ molar ratio were detected in the $\mathrm{AlOH}-\mathrm{MMT}$ concomitant with the decrease of $\mathrm{Na}_{2} \mathrm{O}$ quantity as shown in Table 1, indicating the successful interaction of aluminum polyhydroxy cation in the interlayer space of MMT.

After $\mathrm{Cu}^{2+}$ impregnation into the AlOH-MMT and calcination, the $d_{001}$ peak almost disappeared from the XRD patterns of all $\mathrm{Cu}$-iAlpill-MMTs as shown in Fig. 2 (c-f). These results suggested that the impregnated $\mathrm{Cu}^{2+}$ could penetrate into the interlayer space of AlOH-MMT, bringing about the delamination of MMT tactoids. The impregnated $\mathrm{Cu}^{2+}$ was calcined to $\mathrm{CuO}$, therefore, the crystalline peak of $\mathrm{CuO}$ phase was also observed in the $\mathrm{XRD}$ patterns of all $\mathrm{Cu}$-iAlpill-MMTs at $2 \theta=35.5^{\circ}$. The presence of impregnated $\mathrm{CuO}$ in the $\mathrm{Cu}$-iAlpill-MMTs was also detected by the XRF analyses as reported in Table 1 . The increases of $\mathrm{CuO}$ amount and $\mathrm{Cu} / \mathrm{Si}$ molar ratio in the $\mathrm{Cu}$-iAlpill-MMTs were in agreement with the $\mathrm{Cu}^{2+}$ amount used in the impregnation process.

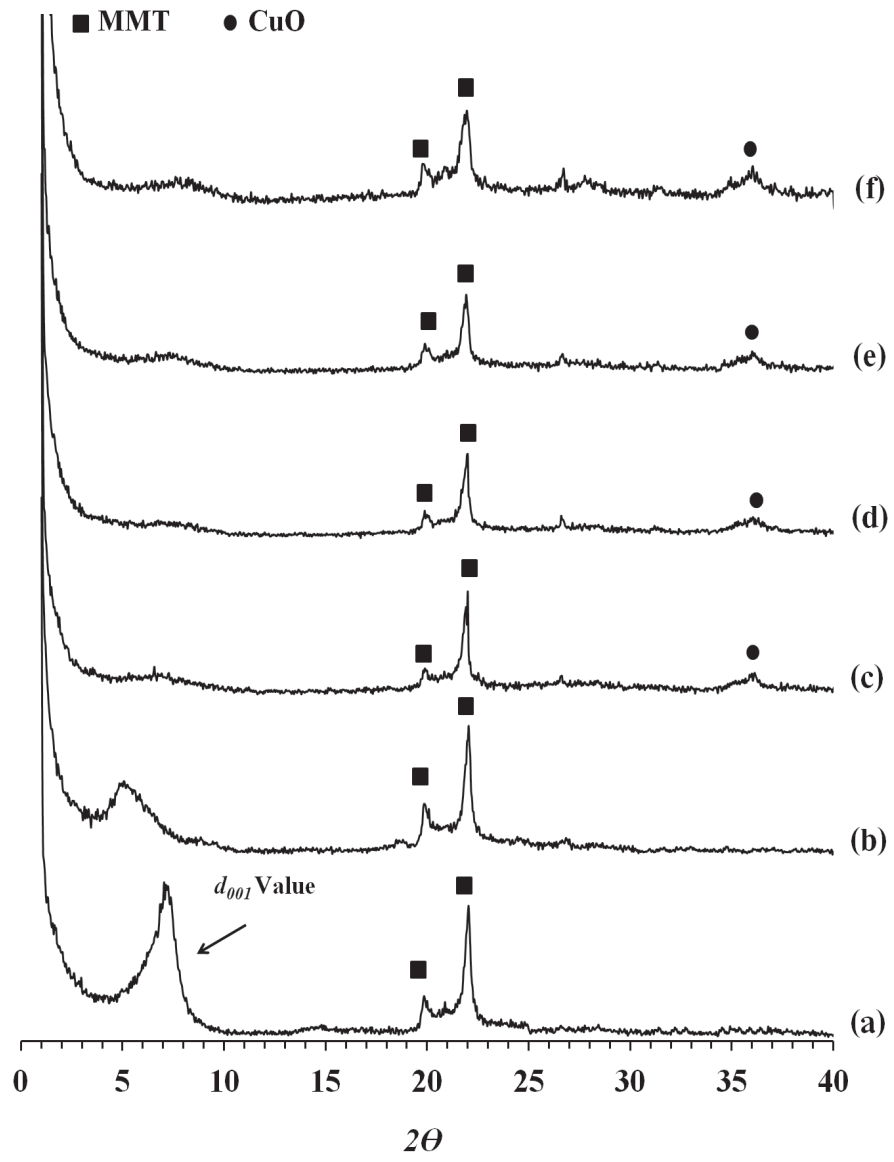

Fig. 2. XRD patterns of (a) $\mathrm{Na}^{+}-\mathrm{MMT}$, (b) AlOH-MMT, (c) Cu-iAlpill-MMT-4wt\%, (d) Cu-iAlpill-MMT-7wt\%, (e) Cu-iAlpill-MMT-10wt\% and (f) Cu-iAlpill-MMT-13wt \%

Table 1

Chemical composition, basal spacing $\left(\mathrm{d}_{001}\right)$, specific surface area (SSA), pore volume and BJH pore diameter of $\mathrm{Na}^{+}-\mathrm{MMT}$, AlOH-MMT and Cu-iAlpill-MMTs

\begin{tabular}{|c|c|c|c|c|c|c|c|c|c|c|c|}
\hline \multirow[b]{2}{*}{ Sample } & \multicolumn{7}{|c|}{ Chemical composition } & $\begin{array}{c}\text { Basal } \\
\text { spacing }\end{array}$ & \multicolumn{3}{|c|}{$\mathrm{N}_{2}$ adsorption } \\
\hline & $\begin{array}{l}\mathrm{Al}_{2} \mathrm{O}_{3} \\
(\mathrm{wt} \%)\end{array}$ & $\begin{array}{c}\mathrm{SiO}_{2} \\
(\mathrm{wt} \%)\end{array}$ & $\begin{array}{l}\mathrm{Na}_{2} \mathrm{O} \\
(\mathrm{wt} \%)\end{array}$ & $\begin{array}{c}\mathrm{CuO} \\
(\mathrm{wt} \%)\end{array}$ & $\begin{array}{l}\text { Other } \\
\text { (wt } \%)\end{array}$ & $\begin{array}{c}\mathrm{Al} / \mathrm{Si} \\
\text { molar } \\
\text { ratio }\end{array}$ & $\begin{array}{c}\mathrm{Cu} / \mathrm{Si} \\
\text { molar } \\
\text { ratio }\end{array}$ & $\begin{array}{c}d_{001} \\
(\mathrm{~nm})\end{array}$ & $\begin{array}{c}\text { SSA } \\
\left(\mathrm{m}^{2} / \mathrm{g}\right)\end{array}$ & $\begin{array}{c}\text { Pore } \\
\text { volume } \\
\left(\mathrm{cm}^{3} / \mathrm{g}\right)\end{array}$ & $\begin{array}{c}\text { BJH } \\
\text { Pore } \\
\text { diameter } \\
(\mathrm{nm})\end{array}$ \\
\hline $\mathrm{Na}^{+}-\mathrm{MMT}$ & 11.99 & 73.44 & 2.31 & 0.00 & 12.26 & 0.19 & $\mathrm{n} / \mathrm{a}$ & 1.24 & 54 & 0.20 & 3.80 \\
\hline AlOH-MMT & 18.44 & 73.68 & 0.50 & 0.00 & 7.38 & 0.29 & $\mathrm{n} / \mathrm{a}$ & 1.74 & $\mathrm{n} / \mathrm{a}$ & $\mathrm{n} / \mathrm{a}$ & $\mathrm{n} / \mathrm{a}$ \\
\hline Cu-iAlpill-MMT-4 wt\% & 16.17 & 66.65 & 0.22 & 4.92 & 12.04 & 0.29 & 0.06 & Broad peak & 87 & 0.19 & 3.79 \\
\hline Cu-iAlpill-MMT-7 wt\% & 15.83 & 61.65 & 0.23 & 8.35 & 13.94 & 0.30 & 0.10 & Broad peak & 40 & 0.17 & 3.79 \\
\hline Cu-iAlpill-MMT-10 wt\% & 14.98 & 56.23 & 0.14 & 12.13 & 16.52 & 0.31 & 0.16 & Broad peak & 30 & 0.16 & 3.79 \\
\hline Cu-iAlpill-MMT-13 wt\% & 13.95 & 50.56 & 0.16 & 15.40 & 20.23 & 0.32 & 0.23 & Broad peak & 31 & 0.06 & 3.34 \\
\hline
\end{tabular}



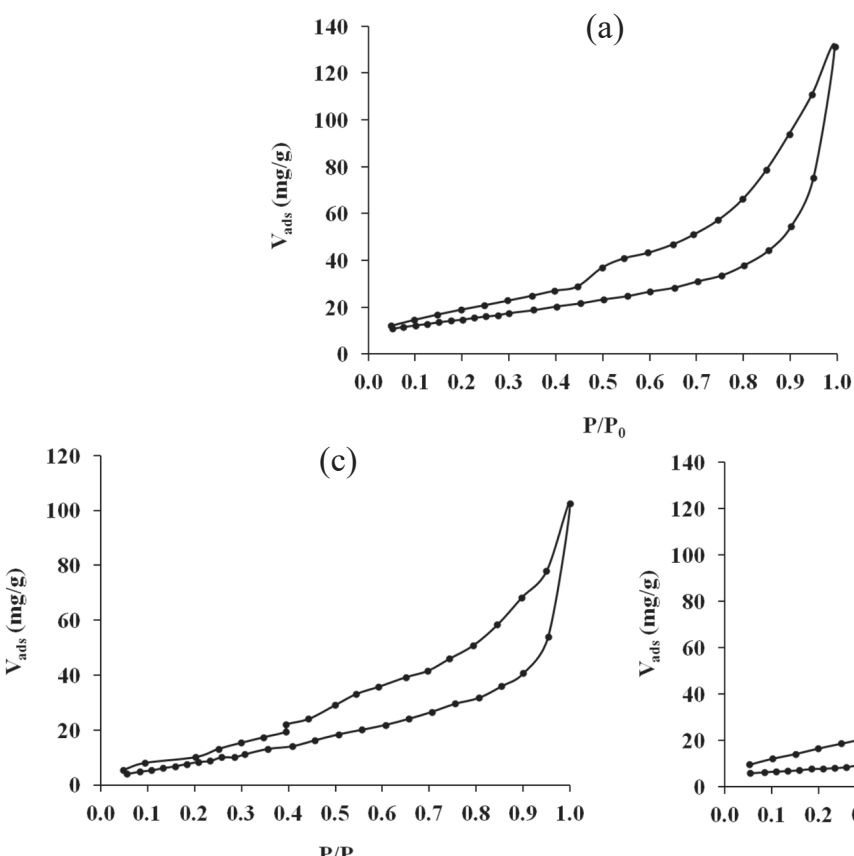

$\mathbf{P} / \mathbf{P}_{0}$

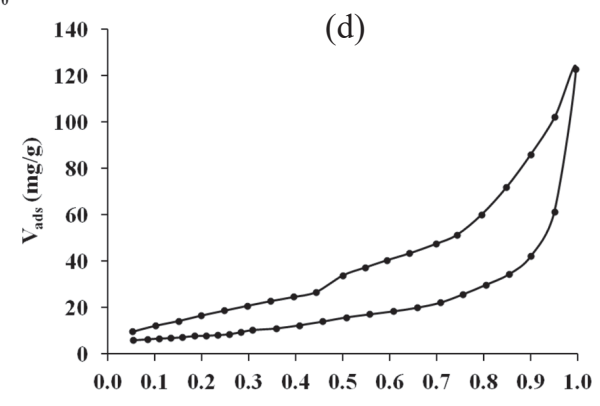

$\mathbf{P} / \mathbf{P}_{0}$
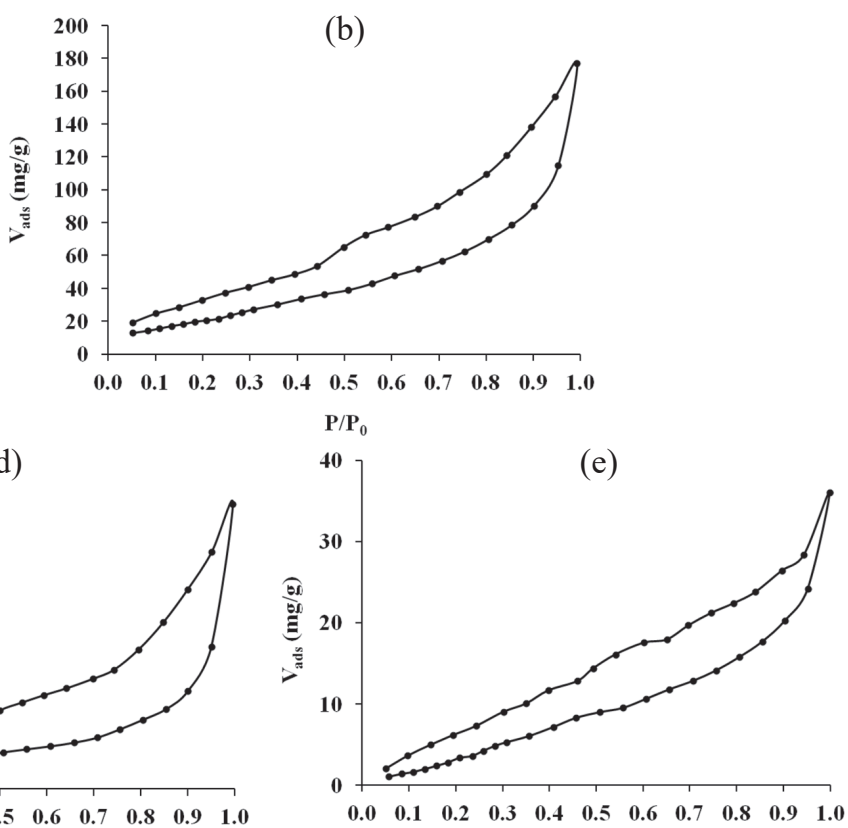

$\mathbf{P} / \mathbf{P}_{0}$

Fig. 3. N2 adsorption isotherms of (a) Na+-MMT, (b) Cu-iAlpill-MMT-4wt\%, (c) Cu-iAlpill-MMT-7wt\%, (d) Cu-iAlpill-MMT-10wt\%, (e) Cu-iAlpill-MMT-13wt\%

Figure 3 shows the $\mathrm{N}_{2}$ adsorption isotherms of the starting $\mathrm{Na}^{+}$-MMT and all $\mathrm{Cu}$-iAlpill-MMTs. The adsorption isotherms of $\mathrm{Na}^{+}$-MMT and $\mathrm{Cu}$-iAlpill-MMTs could be classified as type IV isotherm in the Brunauer, Deming, Dewing and Teller (BDDT) classification, having the hysteresis loop of $\mathrm{H} 3$ type in IUPAC classification [5]. It was, therefore, indicated that the starting $\mathrm{Na}^{+}$-MMT and all $\mathrm{Cu}$-iAlpill-MMTs consisted of slit-like mesopore structures $(2-50 \mathrm{~nm})$. The Brunaur-Emmet-Teller (BET) equation and Barrett-Joyner-Halenda (BJH) method were respectively used for determination of the SSA and average diameter of mesopores as concluded in Table 1. It was found that the SSA and pore volume of the $\mathrm{Cu}-\mathrm{iAl}-$ pill-MMTs decreased with the increase of the impregnated $\mathrm{Cu}$ content. These results were considered to be because the $\mathrm{CuO}$ occupied the interior pores of the Cu-iAlpill-MMTs. The occupancy of $\mathrm{CuO}$ might occur through two main possibilities; i.e. the impregnated $\mathrm{Cu}^{2+}$ ions could coordinate to the oxygens of the MMT silicate layer and/or the oxygens of the aluminum polyhydroxy cations intercalated in the AlOH-MMT precursor. Figure 4 shows the BJH pore size distributions of the starting
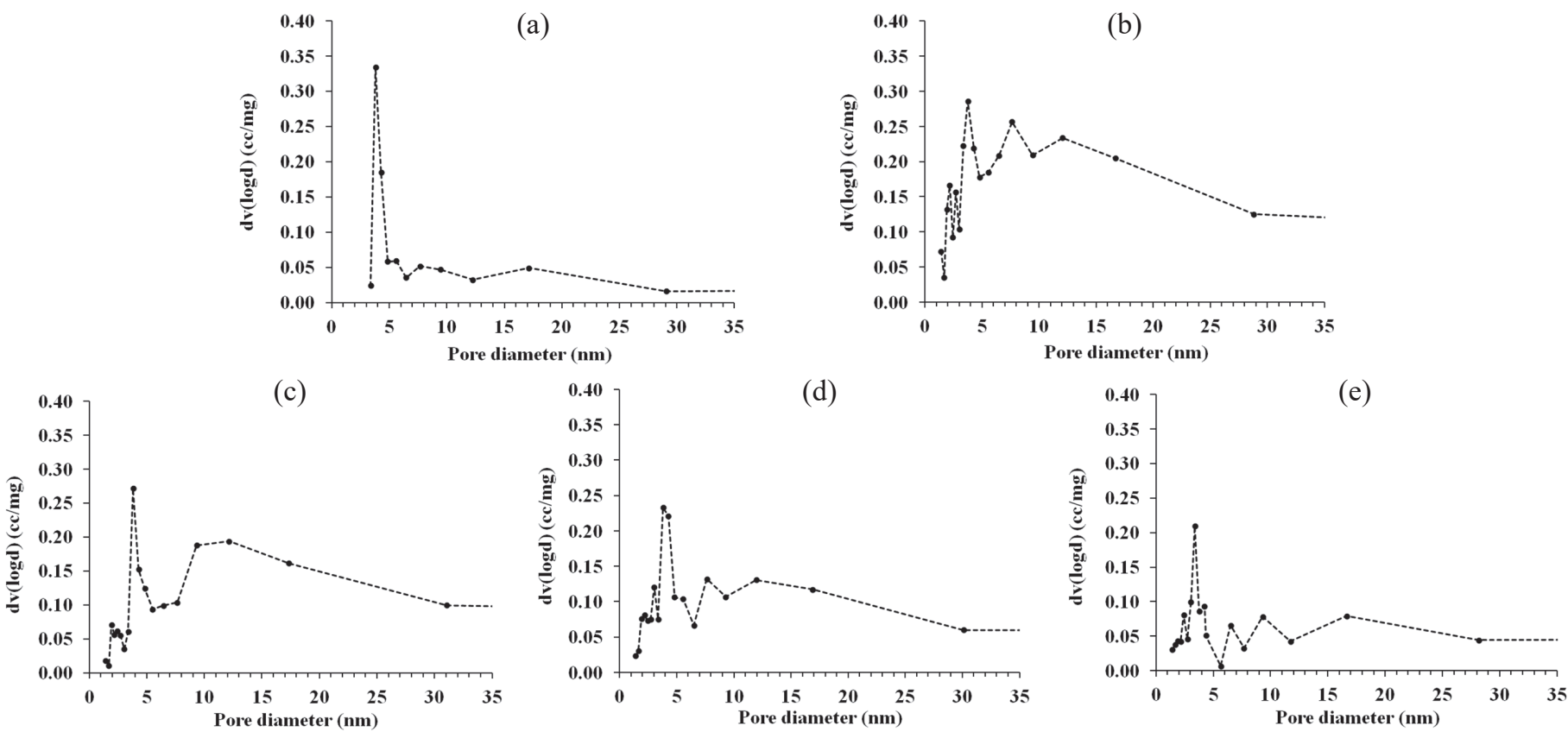

Fig. 4. BJH pore size distributions of (a) Na+-MMT, (b) Cu-iAlpill-MMT-4wt\%, (c) Cu-iAlpill-MMT-7wt\%, (d) Cu-iAlpill-MMT-10wt\%, (e) Cu-iAlpill-MMT-13wt\% 
$\mathrm{Na}^{+}-\mathrm{MMT}$ and all $\mathrm{Cu}$-iAlpill-MMTs. It can be seen that the starting $\mathrm{Na}^{+}$-MMT possessed the mesopores with average pore diameter of about $3.8 \mathrm{~nm}$ as shown in Fig. 4(a). On the other hand, the BJH pore size distributions of all $\mathrm{Cu}$-iAlpill-MMTs have revealed the formation of multiple mesopore sizes ranging from 3.3 to $35 \mathrm{~nm}$ in all $\mathrm{Cu}$-iAlpill-MMTs after intercalation and impregnation treatments as observed in Fig. $4 \mathrm{~b}-\mathrm{e}$. The quantities of mesopores in the Cu-Alpill-MMTs gradually decreased with the increase of the impregnated $\mathrm{Cu}$ content due to the pore-filling with $\mathrm{CuO}$.

Figure 5 shows the SEM micrographs of the $\mathrm{Cu}$-iAlpillMMT surfaces with their $\mathrm{Cu}$ mapping images. The regular distribution of $\mathrm{Cu}$ was observed on the surfaces of all $\mathrm{Cu}$ -

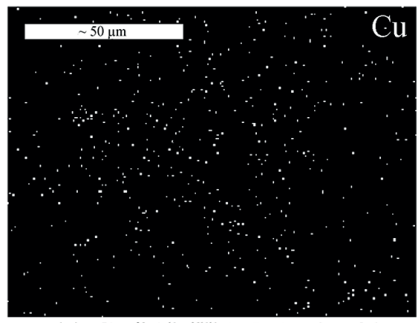

(a) Cu-iAlpill-MMT-4wt\%

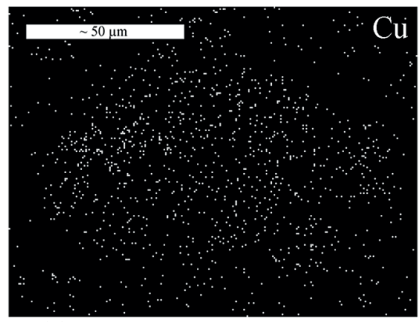

(c) Cu-iAlpill-MMT-10wt\%

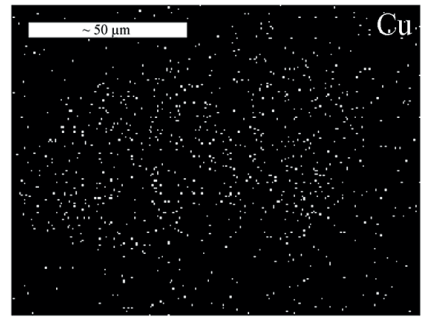

(b) Cu-iAlpill-MMT-7wt\%

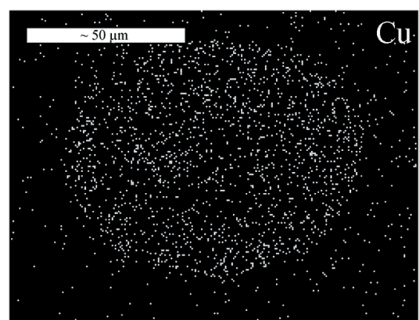

(d) Cu-iAlpill-MMT-13wt \%
Fig. 5. SEM-EDX Cu mapping images of Cu-iAlpill-MMTs surfaces

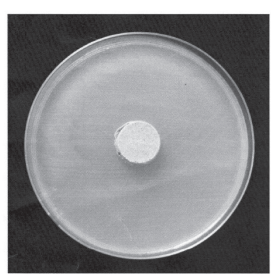

(a) $\mathrm{Na}^{+}$-MMT

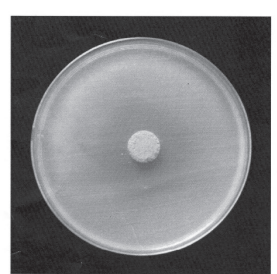

(b) Cu-iAlpill-MMT-4wt $\%$

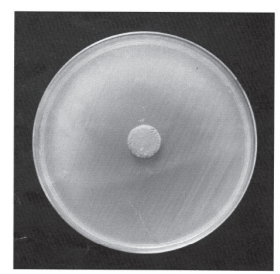

(c) $\mathrm{Cu}-\mathrm{iAlpill}-\mathrm{MMT}-7 \mathrm{wt} \%$

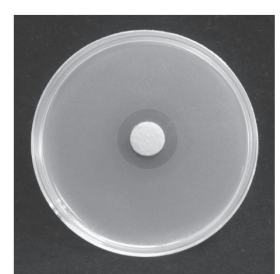

(d) Cu-iAlpill-MMT-10wt $\%$

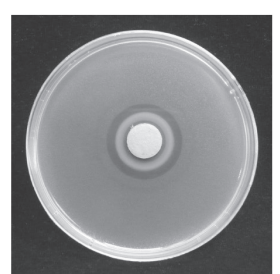

(e) Cu-iAlpill-MMT- $13 w t \%$
Fig. 6. Antibacterial activities of Na+-MMT and $\mathrm{Cu}$-iAlpill-MMTs for E. coli growth
iAlpill-MMT samples, suggesting that the impregnated $\mathrm{Cu}^{2+}$ ions occupied not only the AlOH-MMT interlayers but also the AlOH-MMT surfaces. The quantity of $\mathrm{Cu}$ observed on the EDX mappings of the $\mathrm{Cu}$-iAlpill-MMT surfaces increased with the increase of $\mathrm{Cu}^{2+}$ amount used in the impregnation process.

3.2. Antibacterial activity. Figure 6 shows the antibacterial activities of $\mathrm{Cu}$-iAlpill-MMTs in comparison with the starting $\mathrm{Na}^{+}$-MMT. It was found that the growth of $E$. coli was observed under the $\mathrm{Na}^{+}$-MMT, $\mathrm{Cu}-\mathrm{iAlpill}-\mathrm{MMT}-4 \mathrm{wt} \%$ and $\mathrm{Cu}-\mathrm{A} A$ lpill-MMT-7wt $\%$ samples. However, the clear inhibition zones of about 5.5 and $8.5 \mathrm{~mm}$ in diameter were obtained under the Cu-iAlpill-MMT-10wt\% and Cu-iAlpill-MMT-13wt\% samples, respectively. The antibacterial activities of $\mathrm{Cu}-\mathrm{iAl}-$

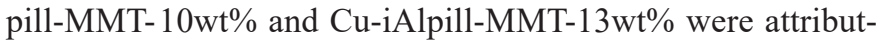
ed to their high impregnated $\mathrm{CuO}$ quantities; therefore, they could release the high amount of $\mathrm{Cu}^{2+}$ ions. The $\mathrm{Cu}^{2+}$ ions could electrostatically interact with the negatively charged cell wall of $E$. coli, resulting in death and/or disability in replication of bacteria. In addition, the $\mathrm{Cu}$-iAlpill-MMT-10wt\% and $\mathrm{Cu}-$ iAlpill-MMT-13wt \% were composed of $\mathrm{CuO}$ rich surfaces, in which they could generate the reactive oxygen species (ROS) such as $\mathrm{HO}^{--}, \mathrm{O}_{2}{ }^{-2-}, \mathrm{HO}_{2}{ }^{\cdot-}$ and $\mathrm{H}_{2} \mathrm{O}_{2}$ in aqueous suspensions. The ROS further interacted with the $E$. coli cell, destroying the cell integrity [19].

3.3. RO16 removal. The percentages of RO16 removal when using the $\mathrm{Cu}$-iAlpill-MMTs in the Fenton and photo-Fenton systems were summarized in Table 2.

A. Fenton system. Figures $7 \mathrm{a}$ and $7 \mathrm{~b}$ show the percentages of color and TOC removals of all $\mathrm{Cu}$-iAlpill-MMTs in the presence of $\mathrm{H}_{2} \mathrm{O}_{2}$, respectively. It was found that the percentages of color and TOC removals gradually increased as reaction time and $\mathrm{Cu}^{2+}$ amount used in the impregnation process increased. The Cu-iAlpill-MMT-13wt\% exhibited the highest ability for RO16 removal even though it possessed the lowest pore volume, suggesting that the $\mathrm{Cu}$-iAlpill-MMTs tend to act more as the heterogeneous catalysts for the degradation of RO16 molecules than the simple adsorbents. The catalytic degradation of RO16 was considered to be initiated by the $\mathrm{Cu}^{2+}$ ions leached out from the $\mathrm{CuO}$ in both interior pores and surfaces of the $\mathrm{Cu}-\mathrm{iAl}-$ pill-MMTs. The $\mathrm{Cu}^{2+}$ ions could promote the decomposition of $\mathrm{H}_{2} \mathrm{O}_{2}$ to strong oxidizing species, i.e. hydroperoxyl radical $(\mathrm{HOO} \bullet)$ and hydroxyl $(\mathrm{HO} \bullet)$ as reported elsewhere [20-22]. These reactive radicals could oxidize the RO16 molecules, causing the cleavages of azo linkage $(-\mathrm{N}=\mathrm{N}-)$, $\mathrm{C}-\mathrm{S}$ bond between the aromatic ring and sulfonate group, $\mathrm{C}-\mathrm{N}$ bond between the naphthalene ring and azo group and aromatic ring opening [23]. These oxidation reactions resulted in the decolorization of RO16 due to the degradation of chromophore and auxochrome, which are responsible for their color. In addition, the cleavage fragments of oxidized RO16 were considered to be mineralized by the reactive radicals as evidently observed in the significant increase of TOC removal. 
Table 2

Percentages of color and TOC removals of Cu-iAlpill-MMTs in the Fenton (Cu-iAlpill-MMTs $\left./ \mathrm{H}_{2} \mathrm{O}_{2}\right)$ and photo-Fenton systems (Cu-iAlpill-MMTs/ $\left.\mathrm{H}_{2} \mathrm{O}_{2} / \mathrm{UV}\right)$

\begin{tabular}{|c|c|c|c|c|c|c|c|c|c|c|c|c|}
\hline \multirow{3}{*}{ Systems } & \multicolumn{6}{|c|}{ Color removal (\%) } & \multicolumn{6}{|c|}{ TOC removal (\%) } \\
\hline & \multicolumn{6}{|c|}{ Reaction time (min) } & \multicolumn{6}{|c|}{ Reaction time (min) } \\
\hline & 30 & 60 & 90 & 120 & 240 & 360 & 30 & 60 & 90 & 120 & 240 & 360 \\
\hline $\mathrm{Cu}-\mathrm{iAlpill}-\mathrm{MMT}-4 \mathrm{wt} \% / \mathrm{H}_{2} \mathrm{O}_{2}$ & - & 54 & - & 68 & 80 & 88 & - & 36 & - & 52 & 75 & 81 \\
\hline $\mathrm{Cu}-\mathrm{iAlpill}-\mathrm{MMT}-4 \mathrm{wt} \% / \mathrm{H}_{2} \mathrm{O}_{2} / \mathrm{UV}$ & 44 & 63 & 69 & 75 & 86 & 89 & 35 & 48 & 56 & 65 & 80 & 81 \\
\hline $\mathrm{Cu}-\mathrm{iAlpill}-\mathrm{MMT}-7 \mathrm{wt} \% / \mathrm{H}_{2} \mathrm{O}_{2}$ & - & 61 & - & 77 & 89 & 94 & - & 45 & - & 64 & 85 & 93 \\
\hline $\mathrm{Cu}-\mathrm{iAlpill}-\mathrm{MMT}-7 \mathrm{wt} \% / \mathrm{H}_{2} \mathrm{O}_{2} / \mathrm{UV}$ & 74 & 82 & 91 & 94 & 97 & 98 & 67 & 80 & 89 & 91 & 93 & 95 \\
\hline $\mathrm{Cu}-\mathrm{iAlpill}-\mathrm{MMT}-10 \mathrm{wt} \% / \mathrm{H}_{2} \mathrm{O}_{2}$ & - & 70 & - & 83 & 94 & 99 & - & 56 & - & 74 & 88 & 96 \\
\hline $\mathrm{Cu}-\mathrm{i}$ Alpill-MMT-10wt $\% / \mathrm{H}_{2} \mathrm{O}_{2} / \mathrm{UV}$ & 98 & 99 & 100 & 100 & 100 & 100 & 93 & 99 & 98 & 100 & 100 & 100 \\
\hline $\mathrm{Cu}-\mathrm{iAlpill}-\mathrm{MMT}-13 \mathrm{wt} \% / \mathrm{H}_{2} \mathrm{O}_{2}$ & - & 73 & - & 85 & 95 & 99 & - & 58 & - & 74 & 88 & 97 \\
\hline $\mathrm{Cu}-\mathrm{iAlpill}-\mathrm{MMT}-13 \mathrm{wt} \% / \mathrm{H}_{2} \mathrm{O}_{2} / \mathrm{UV}$ & 98 & 100 & 100 & 100 & 100 & 100 & 95 & 99 & 100 & 100 & 100 & 100 \\
\hline
\end{tabular}

B. Photo-Fenton system. Figures $8 \mathrm{a}$ and $8 \mathrm{~b}$ show the percentages of color and TOC removals of all $\mathrm{Cu}$-iAlpill-MMTs in the presence of $\mathrm{H}_{2} \mathrm{O}_{2}$ and $\mathrm{UV}$ radiation, respectively. Under the UV radiation, all Cu-iAlpill-MMT catalysts exhibit significantly higher color and TOC removals than those performed without UV radiation using the same reaction time. These results were attributed to the synergistic effect of UV radiation and $\mathrm{Cu}^{2+}$ ions leached from the $\mathrm{Cu}$-iAlpillMMTs on the rapid degradation of $\mathrm{H}_{2} \mathrm{O}_{2}$ and $\mathrm{H}_{2} \mathrm{O}$ into the $\mathrm{HO} \cdot$ radicals, bringing about the faster decolorization and mineralization of RO16 molecules. The systems with the higher $\mathrm{Cu}$ content in the $\mathrm{Cu}$-iAlpill-MMTs and/or the longer reaction time exhibited the higher percentages of colour and TOC removals. However, the efficiency of RO16 removal of $\mathrm{Cu}-\mathrm{iAlpill-MMT-10wt \%}$ was quite close to that of $\mathrm{Cu}-$ iAlpill-MMT-13wt\%, although the $\mathrm{Cu}$ content in the $\mathrm{Cu}-$ iAlpill-MMT-10wt\% was lower than that in the Cu-iAlpillMMT-13wt $\%$. This result was considered to be caused by the fact that the excess $\mathrm{Cu}$ in the $\mathrm{Cu}$-iAlpill-MMT-13wt \% which formed as $\mathrm{CuO}$ clusters on its exterior surface might partially hinder the migration of $\mathrm{Cu}^{2+}$ ions leached from the interior. It was, therefore, both $\mathrm{Cu}$-iAlpill-MMT-10wt $\%$ and $\mathrm{Cu}-\mathrm{iAlpill-}$ MMT-13wt\% could completely eliminate the RO16 within $60 \mathrm{~min}$ when using the photo-Fenton systems.
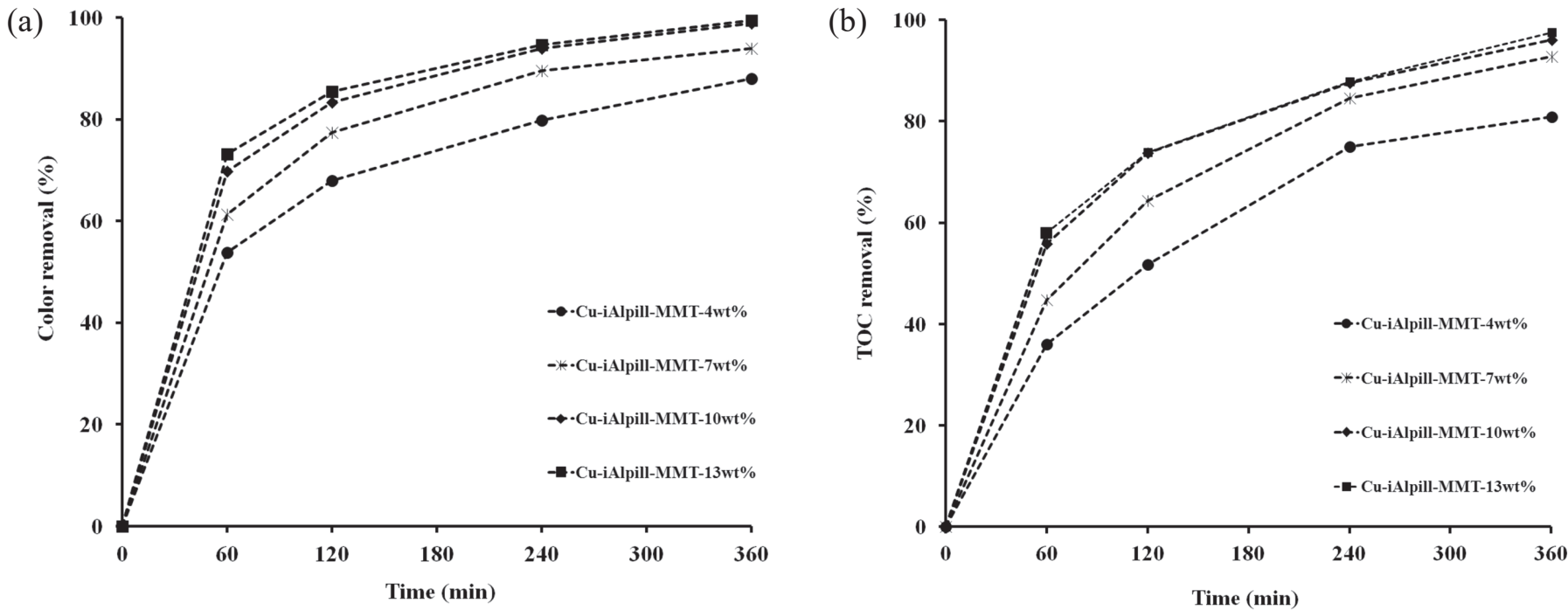

Fig. 7. Efficiencies of Cu-iAlpill-MMTs for (a) colour and (b) TOC removals in Fenton systems 
(a)

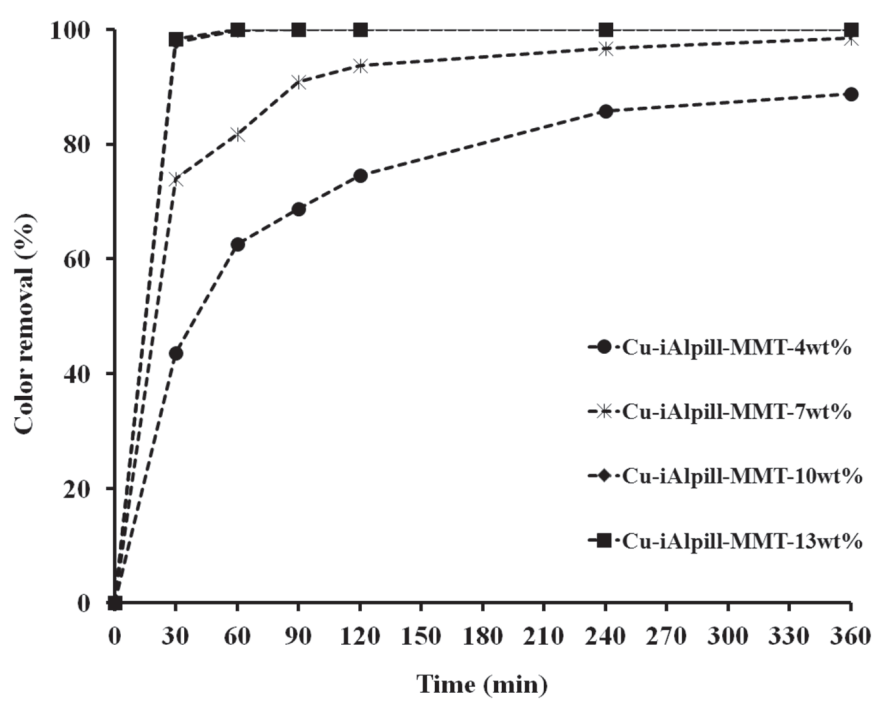

(b)

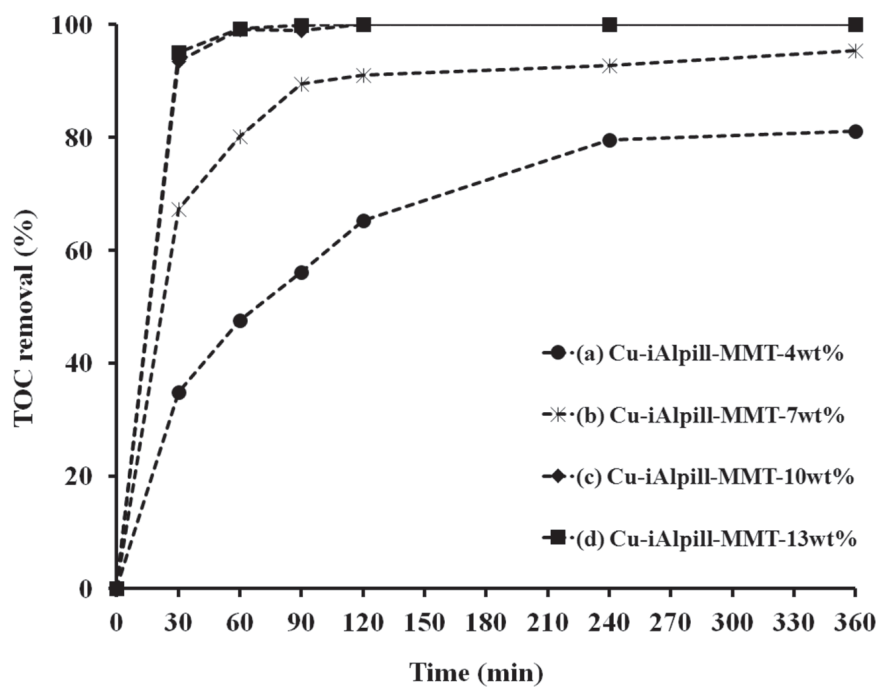

Fig. 8. Efficiencies of Cu-iAlpill-MMTs for (a) colour and (b) TOC removals in photo-Fenton systems

\section{Conclusions}

Copper impregnated aluminum pillared montmorillonites $(\mathrm{Cu}-$ iAlpill-MMTs) were successfully prepared by direct impregnation of $\mathrm{CuSO}_{4} \cdot 5 \mathrm{H}_{2} \mathrm{O}$ aqueous solution into the precursor of aluminum polyohydroxy cation montmorillonite (AlOH-MMT). The impregnated $\mathrm{Cu}$ was calcined to $\mathrm{CuO}$ crystalline phase which occupied not only the interior interlayers but also the exterior surfaces of aluminum pillared montmorillonites. The slit-liked mesopore structures were obtained in the $\mathrm{Cu}$-iAlpillMMTs, in which the specific surface area and pore volume of $\mathrm{Cu}$-iAlpill-MMTs were slightly decreased when copper loading increased. The $\mathrm{Cu}$-iAlpill-MMTs with $\mathrm{CuO}$ rich surfaces could inhibit the growth of E. coli, indicating their antibacterial activities. In addition, the as-prepared $\mathrm{Cu}$-iAlpill-MMTs could act as heterogeneous catalysts for decolorization and mineralization of reactive orange 16 (RO16) when applying them in the Fenton (Cu-iAlpill-MMT/ $\mathrm{H}_{2} \mathrm{O}_{2}$ ) and photo-Fenton (Cu-iAlpill-MMT/ $\mathrm{H}_{2} \mathrm{O}_{2} / \mathrm{UV}$ ) treatment systems. The percentages of color and TOC removals gradually increased with the increases of the $\mathrm{Cu}$ content in the Cu-iAlpill-MMTs and the treatment times used in the Fenton and photo-Fenton systems. The decolorization and mineralization of RO16 in the Fenton system was faster than those in the photo-Fenton system. The Cu-iAlpill-MMT- $13 \mathrm{wt} \%$ showed the highest and color and TOC removals in both Fenton and photo Fenton systems.

Acknowledgments. The authors would like to acknowledge the financial support from Thai governmental budget for fiscal year 2015 .

\section{REFERENCES}

[1] J. Bovey, F. Kooli, and W. Jones, "Preparation and characterization of Ti-pillared acid-activated clay", Clays. Miner. 31, 501-506 (1996).

[2] J.T. Kloprogge, "Synthesis of smectites and porous pillared clay catalysts: review", J. Porous. Mater. 5, 5-41 (1998).

[3] P. Yuan, H. He, F. Bergaya, D. Wu, Q. Zhou, and J. Zhu, "Synthesis and characterization of delaminated iron-pillared clay with meso-microporous structure", Microporous. Mesoporous. Mater. $88,8-15$ (2006).

[4] H. Guo, X. Jing, L. Zhang, and J. Wang, "Preparation of inorganic-organic pillared montmorillonite using ultrasonic treatment", J. Mater. Sci. 42, 6951-6955 (2007).

[5] P. Tepmatee and P. Siriphannon, "Effect of Preparation Method on Structure and Adsorption Capacity of Aluminium Pillared Montmorillonite", Mater. Res. Bull. 48, 4856-4866 (2013).

[6] K. Pirkanniemi and M. Sillanpaa, "Heterogeneous water phase catalysis as an environmental application: a review", Chemosphere 48, 1047-1060 (2002).

[7] M.A. Vicente, C. Belver, R. Trujillano, M.A. Bañares-Muñoz, V. Rives, S.A. Korili, A. Gil, L.M. Gand'1a, and J.F. Lambert, "Preparation and characterisation of vanadium catalysts supported over alumina-pillared clays", Catal. Today. 78, 181-190 (2003).

[8] E.G. Garrido-Ramírez, B.K.G. Theng, and M.L. Mora, "Clays and oxide minerals as catalysts and nanocatalysts in Fenton-like reactions-A review", Appl. Clay. Sci. 47, 182-192 (2010).

[9] F. Nerud, P. Baldian, J. Gabriel, and D. Ogbeifun, "Decolorization of synthetic dyes by the Fenton reagent and the $\mathrm{Cu} /$ pyridine/ $\mathrm{H}_{2} \mathrm{O}_{2}$ system", Chemosphere 44, 957-961 (2001).

[10] J.K. Kim, F. Martinez, and I.S. Metcalfe, "The beneficial role of use of ultrasound in heterogeneous Fenton-like system over supported copper catalysts for degradation of $p$-chlorophenol", Catal. Today. 124, 224-231 (2007).

[11] S. Xia, L. Hui, Z. Yaobin, Z. Yazhi, and Q. Xie, "Efects of $\mathrm{Cu}(\mathrm{II})$ and humic acid on atrazine photodegradation", J. Environ. Sci. 23(5), 773-777 (2011).

[12] S. Zhou, Z. Qian, T. Sun, J. Xu, and C. Xia, "Catalytic wet peroxide oxidation of phenol over $\mathrm{Cu}-\mathrm{Ni}-\mathrm{Al}$ hydrotalcite", Appl. Clay. Sci. 53, 627-633 (2011). 
[13] S. Caudo, G. Centi, C. Genovese, and S. Perathoner, "Copper and iron-pillared clay catalysts for the WHPCO of model and real wastewater streams from olive oil milling production", Appl. Catal. B-Environ. 70, 437-446 (2007).

[14] S. Caudo, C. Genovese, S. Perathoner, and G. Centi, "Copper-pillared clays (Cu-PILC) for agro-food wastewater purification with $\mathrm{H}_{2} \mathrm{O}_{2}$ ", Microporous. Mesoporous. Mater. 107, 46-57 (2008).

[15] P. Majzlik, A. Strasky, V. Adam, M. Nemec, L. Trnkova, J. Zehnalek, J. Hubalek, I. Provaznik, and R. Kizek, "Influence of zinc(II) and copper(II) ions on streptomyces bacteria revealed by electrochemistry", Int. J. Electrochem. Sci. 6, 2171-2191 (2011).

[16] C. Yu-Hao, H. Chung-Fang, O. Keng-Liang, and P. Pei-Wen, "Mechanical properties and antibacterial activity of copper doped diamond-like carbon films", Surf. Coat. Technol. 206, 1037-1040 (2011).

[17] P. Tepmatee and P. Siriphannon, "Nanoporous copper doped aluminium pillared montmorillonite for dye-containing wastewater treatment", Water. Environ.

Res. doi: 10.2175/106143015X14362865227076 (2015).

[18] R.B. Chavan, "Environment-friendly dyeing processes for cotton", Indian. J. Fibre. Text. 26, 93-100 (2001).
[19] M.S. Hassan, T. Amna, O-B. Yang, M.H. El-Newehy, S.S. Al-Deyab, and M-S. Khil, "Smart copper oxide nanocrystals: Synthesis, characterization, electrochemical and potent antibacterial activity", Colloids. Surf. B. 97, 201-206 (2012).

[20] F. Haber and J. Weiss, "The catalytic decomposition of hydrogen peroxide by iron salts", J. Proc. Roy. Soc. London. A. 147, 332-351 (1934).

[21] M.N. Timofeeva, S.Ts. Khankhasaeva, E.P. Talsi, V.N. Panchenko, A.V. Golovin, E.Ts. Dashinamzhilova, and S.V. Tsybulya, "The effect of $\mathrm{Fe} / \mathrm{Cu}$ ratio in the synthesis of mixed $\mathrm{Fe}, \mathrm{Cu}$, Al-clays used as catalysts in phenol peroxide oxidation", Appl. Catal. B: Environ. 90, 618-627 (2009).

[22] F.V.F Araujo, L. Yokoyama, L.A.C. Teixeira, and J.C. Campos, "Heterogeneous Fenton process using the mineral hematite for the discolouration of a reactive dye solution", Braz. J. Chem. Eng. 28, 605-616 (2011).

[23] S.S. Kumar, T. Muruganandham, and M.S.M. Jaabir, "Decolourization of Azo dyes in a two-stage process using novel isolate and advanced oxidation with Hydrogen peroxide / HRP system", Int. J. Curr. Microbiol. App. Sci. 3, 514-522 (2014). 